\title{
Correction to: Vibro-impact system with non-ideal excitation: analytical investigations
}

\author{
Miodrag Zukovic • Dzanko Hajradinovic (D) Ivana Kovacic
}

Published online: 22 November 2021

(C) Springer Nature B.V. 2021

Correction to: Nonlinear Dyn (2021) 106:105-123

https://doi.org/10.1007/s11071-021-06842-0

The original article was published with erroneous affiliation information. The original article has been corrected.
Publisher's Note Springer Nature remains neutral with regard to jurisdictional claims in published maps and institutional affiliations.

The original article can be found online at https:// doi.org/10.1007/s11071-021-06842-0.

M. Zukovic · I. Kovacic

Centre for Vibro-Acoustic Systems and Signal Processing, Faculty of Technical Sciences, University of Novi Sad,

Novi Sad, Serbia

e-mail: zukovic@uns.ac.rs

I. Kovacic

e-mail: ivanakov@uns.ac.rs

D. Hajradinovic $(\bowtie)$

Department of Mechanics, Faculty of Mechanical

Engineering, University of Sarajevo, Sarajevo, Bosnia and Herzegovina

e-mail: hajradinovic@mef.unsa.ba 